\title{
Establishment and Characterization of Monoclonal Antibodies Against SARS Coronavirus
}

\author{
Kazuo Ohnishi
}

\begin{abstract}
Immunological detection of viruses and their components by monoclonal antibodies is a powerful method for studying the structure and function of viral molecules. Here we describe detailed methods for establishing monoclonal antibodies against severe acute respiratory syndrome coronavirus (SARS-CoV). B cell hybridomas are generated from mice that are hyperimmunized with inactivated SARS-CoV virions. The hybridomas produce monoclonal antibodies that recognize viral component molecules, including the spike protein $(\mathrm{S})$ and the nucleocapsid protein $(\mathrm{N})$, enabling the immunological detection of SARS-CoV by immunofluorescence staining, immunoblot, or an antigen-capture ELISA system. In addition, several S protein-specific antibodies are shown to have in vitro neutralization activity. Thus the monoclonal antibody approach provides useful tools for rapid and specific diagnosis of SARS, as well as for possible antibody-based treatment of the disease.
\end{abstract}

Key words: monoclonal antibody; SARS-CoV; coronavirus; immunization; confocal immunofluorescence; Western blot; antigen-capture sandwich ELISA.

\section{Introduction}

The outbreak of severe acute respiratory syndrome (SARS) in 2003 ultimately led to 8000 people becoming infected, 916 of whom died. The causative agent was identified as SARS coronavirus (SARS-CoV) $(1,2)$. Even though the epidemic ended, the threat of reemergence persists, compounded by the absence of an established vaccine. One of the critical issues in controlling a pandemic is a system for early diagnosis that distinguishes SARS from other

From: Methods in Molecular Biology, vol. 454: SARS- and Other Coronaviruses,

Edited by: D. Cavanagh, DOI: 10.1007/978-1-59745-181-9_15, C Humana Press, New York, NY 
types of pulmonary infections. Based on clinical experience, several options have been considered in the quest to develop the capacity to accurately diagnose SARS-CoV infection, including molecular biology techniques and serological tests such as antigen-capture ELISA assay and immunofluorescence assay to detect virus-infected cells in respiratory swabs (3-7). The preparation of monoclonal antibodies (mAbs) is considered to be especially valuable for serological testing. Here we describe a method for the successful establishment and characterization of mAbs against SARS-CoV structural components. These mAbs enable the general immunological detection of SARS-CoV by methods such as immunofluorescent staining, immunoblotting, and immunohistology, in addition to the construction of a highly sensitive antigen-capture sandwich ELISA (6).

\section{Materials}

\subsection{Immunization of Mice with UV-Inactivated SARS-CoV}

1. SARS-CoV, strain HKU-39849, is expanded, purified, and inactivated by the method described in Chapter 11.

2. BALB/c mice, 8- to 10-week-old females, (Japan SLC, Shizuoka, Japan).

3. Freund's complete adjuvant.

4. Freund's incomplete adjuvant.

\subsection{Cell Fusion and Hybridoma Production}

1. Cell-passage medium: RPMI1640 medium (Gibco/Invitrogen) supplemented with $10 \%$ fetal bovine serum (FBS), $5 \times 10^{-5} \mathrm{M}$ 2-mercaptoethanol, 1/100 volume of nonessential amino acid solution (NEAA, Gibco/Invitrogen), 1/100 volume of $200 \mathrm{mM}$ GlutaMAX $^{\mathrm{TM}}$ solution (Gibco/Invitrogen) and 1/100 volume of penicillin $(100 \mathrm{U} / \mathrm{mL}) /$ streptomycin $(100 \mu \mathrm{g} / \mathrm{ml})$ solution.

2. Fusion partner myeloma cell line: Sp2/O-Ag14 (ATCC CRL-1581) is maintained with cell-passage medium at $37^{\circ} \mathrm{C}$ in a $5 \% \mathrm{CO}_{2}$ incubator.

3. Polyethylene glycol reagent: PEG4000 (Sigma) is aliquoted to $2 \mathrm{~g}$ in glass tubes with lids and autoclaved. Aliquots can be stored at room temperature.

4. Hybridoma medium: RPMI1640 is supplemented with $15 \% \mathrm{FCS}, 0.2 \mathrm{ng} / \mathrm{ml} \mathrm{recom-}$ binant mouse IL-6 (R \& D Systems, MN, USA), $5 \times 10^{-5}$ M 2-mercaptoethanol, $1 / 100$ volume of nonessential amino acids, $1 / 100$ volume of GlutaMAX ${ }^{\mathrm{TM}}$, and $1 / 100$ volume of penicillin/streptomycin solution.

5. HAT-selection medium: HAT supplement solution (Gibco/Invitrogen) is added to the hybridoma medium at a ratio of $1 / 50$.

6. HT-medium: HT supplement solution (Gibco/Invitrogen) is added to the hybridoma medium at a ratio of $1 / 100$.

7. Serum-free hybridoma medium: Hybridoma-SFM medium (Gibco/Invitrogen) is supplemented with $0.2 \mathrm{ng} / \mathrm{ml}$ recombinant mouse IL- 6 and $1 / 100$ volume of penicillin/streptomycin solution. 


\subsection{Screening of Anti-SARS-CoV-Producing Hybridomas}

1. NP-40 lysis buffer: $1 \%$ NP-40, $150 \mathrm{mM} \mathrm{NaCl}, 50 \mathrm{mM}$ Tris- $\mathrm{HCl}$ (pH 7.5). Stored at room temperature.

2. SARS-CoV-infected Vero E6 cells: SARS-CoV-infected Vero E6 cells are cultured and UV-inactivated by the method described in Chapter 11.

3. ELISA-coating buffer: $50 \mathrm{mM}$ sodium bicarbonate. The $\mathrm{pH}$ is about 9.5 without adjusting.

4. ELISA plates: Nunc-Immunoplate F96.Cert Maxisorp (Nunc, Denmark).

5. PBS-Tween: $10 \mathrm{mM}$ phosphate buffer (pH 7.5), $140 \mathrm{mM} \mathrm{NaCl}, 0.05 \%$ Tween 20.

6. Blocking solution: $1 \%$ ovalbumin (OVA) in PBS-Tween.

7. Detecting (second) antibody: Alkaline phosphatase-conjugated anti-mouse IgG (1:2000 dilution, Zymed, South San Francisco, CA).

8. ELISA substrate: $p$-Nitrophenyl Phosphate Liquid Substrate System (PNPP, Sigma).

9. Cell-freezing solution: $8 \%$ dimethylsulfoxide/92\%FCS.

\subsection{Purification of Anti-SARS-CoV Monoclonal Antibody}

1. Serum-free hybridoma medium (see Section 2.2, step 7).

2. Protein G resin: Protein G-Sepharose 6B column (GE Healthcare/Amersham, UK).

3. Glycine/ $\mathrm{HCl}$ solution: $100 \mathrm{mM}$ Glycine, $\mathrm{pH} 2.8$ with $\mathrm{HCl}$.

4. Saturated $\left(\mathrm{NH}_{4}\right)_{2} \mathrm{SO}_{4}$ : Excess $\left(\mathrm{NH}_{4}\right)_{2} \mathrm{SO}_{4}$ is added to distilled water and stored at $4^{\circ} \mathrm{C}$. The supernatant is used.

\subsection{Biotinylation of Monoclonal Antibodies}

1. Biotinylation reagent: Sulfo-NHS-LC-biotin (Pierce, Rockford, IL).

2. Sodium bicarbonate buffer: $50 \mathrm{mM}$ sodium bicarbonate buffer, $\mathrm{pH}$ should be about 8.5 without adjustment.

\subsection{Immunofluorescence Assay}

1. Chamber slides: Lab-Tek 8-well glass chamber slides (Nunc, Denmark).

2. IFA-staining buffer: $1 \%$ BSA (Sigma) in PBS. Sodium azide is added to $0.05 \%$ as preservative.

3. Paraformaldehyde solution: $4 \%$ paraformaldehyde is freshly dissolved in PBS by heating to $70^{\circ} \mathrm{C}$. Use cold.

4. PBS/TritonX-100 solution: $0.1 \%$ Triton $\mathrm{X}-100$ in PBS.

5. DAPI solution: For the stock solution, 4,6-diamidino-2-phenylindole hydrochloride (DAPI, Invitrogen) is dissolved with DW at $5 \mathrm{mg} / \mathrm{ml}$ and stored at $-20^{\circ} \mathrm{C}$. Use with $300 \mathrm{nM}$ (1/48,000 dilution).

6. Mounting solution: Fluoromount G (SouthernBiotech, Birmingham, Alabama USA). 


\subsection{Immunoblot with Monoclonal Antibodies}

1. Blot membrane: PVDF membrane (Bio-Rad, CA, USA).

2. Blocking reagent: Starting Block ${ }^{\mathrm{TM}}$ (Pierce, USA).

3. Detecting (second) antibody: Peroxidase-conjugated $\mathrm{F}\left(\mathrm{ab}^{\prime}\right)_{2}$ fragment anti-mouse $\operatorname{IgG}(\mathrm{H}+\mathrm{L})$ (use with 1:20,000 dilution, Jackson Immuno Research, West Grove, PA).

4. Chromatography paper: 3 MM CHR (Whatman, UK).

5. X-ray film (Kodak, Rochester, NY).

6. Chemiluminescent reagent: SuperSignal West Femto (Pierce, USA).

\subsection{Antigen-Capture Sandwich ELISA}

1. High-binding immunoassay microplate: Immulon-2 (Dynatech Labs, VA, USA) or the equivalent.

2. ELISA-coating buffer: (see Section 2.3, step 3).

3. Blocking solution: $1 \%$ OVA in PBS-Tween.

4. Detecting (second) reagent: $\beta$-D-galactosidase-labeled streptavidine (Zymed, San Francisco, CA).

5. Galactosidase substrate: 4-Methy-lumbelliferyl- $\beta$-D-galactoside (Sigma).

6. Reaction stop solution: $0.1 \mathrm{M}$ Glycine- $\mathrm{NaOH}$ ( $\mathrm{pH} 10.2)$.

\section{Methods}

The viruses generally elicit strong humoral immune response in mice and hence are good antigens for obtaining the mAbs. The SARS-CoV also raises a high titer of serum antibody in mice. However, the immunization protocol should be optimized to obtain the desired specificity and quality of mAbs of interest. The choice of parameters for immunization, such as the type of adjuvant, pretreatment of viral antigens (inactivation procedures), antigen dose, route of immunization, and the strain of mice, profoundly affect the properties of resulting mAbs. For example, we found that inactivation of SARS-CoV with UV or formaldehyde gave rise to different immunoglobulin isotypes in mice (8). In addition, the choice of host animals for the immunization affects the mode of epitope recognition. With the common fusion-partner cell lines such as NS-1, P3U1, or Sp2/O, a variety of mouse strains, even different species such as rat and hamsters, are usable for the donor of antigen-specific B cells. However, $\mathrm{BALB} / \mathrm{c}$ mice are the most commonly used immunization host because the most efficient fusion-partner myelomas are derived from BALB/c strain. The protocol described here is a general procedure to obtain mAbs against viral antigens, though the choice of parameters, i.e., the immunization protocol, hybridoma production and so on, should be optimized for each purpose (see Note 1). 


\subsection{Immunization of Mice with UV-Inactivated SARS-CoV}

1. BALB/c mice are immunized subcutaneously with $20 \mu \mathrm{g}$ of UV-inactivated purified SARS-CoV using Freund's complete adjuvant (FCA).

2. After 2 weeks, the mice are boosted with subcutaneous injection of $5 \mu \mathrm{g}$ of UVinactivated SARS-CoV using Freund's incomplete adjuvant (FIA).

3. On day 3 after the boost, sera from the mice are tested by ELISA (see Section 3.3) for the antibody titer against SARS-CoV.

4. The two mice showing the highest antibody titer are further boosted intravenously with $5 \mu \mathrm{g}$ of the inactivated virus 14 days after the previous boost.

5. If the antibody titer is lower than expected, the booster injection can be repeated several times before the final boost.

\subsection{Cell Fusion and Hybridoma Production}

Three days after the final boost, spleen cells from immunized mice are fused with Sp2/O-Ag14 myeloma by the polyethylene glycol method of Kosbor et al. (9) (see Section 3.2, step 5. This protocol gave rise to more than 40 candidate hybridomas, some of which react with $\mathrm{S}$ and N protein of SARS-CoV (Table 1).

1. For 1 to $2 \mathrm{~h}$ before cell-fusion, $2 \mathrm{~g}$ of PEG in a sterile glass tube is melted in a microwave oven and dissolved in $2.4 \mathrm{ml}$ of RPMI1640 (abbreviated as RPMI hereafter), prewarmed to $37^{\circ} \mathrm{C}$, by repeated pipetting. The PEG solution is kept at $37^{\circ} \mathrm{C}$ for at least $1 \mathrm{~h}$.

2. One or two spleens from mice are excised and the spleen cell suspension is prepared by passing through a sterile stainless mesh or by smashing with two slide glasses. The cells are washed by centrifugation $(270 \times g$ for $5 \mathrm{~min})$ twice with $5 \%$ FCS/RPMI and once with RPMI.

3. The log-phase growing Sp2/O-Ag14 myeloma cells are washed twice with 5\% FCS/RPMI and once with RPMI.

\section{Table 1}

Summary of the First Hybridoma Screening by ELISA ${ }^{a}$

\begin{tabular}{lccr}
\hline Immobilized antigen & Experiment 1 & Experiment 2 & Total \\
\hline (Total wells assayed) & 1920 & 960 & 2880 \\
SARS-CoV infected & 28 & 14 & 42 \\
Vero cell-lysate & & & \\
Recombinant-S & 19 & 7 & 26 \\
Recombinant-N & 3 & 0 & 3 \\
\hline
\end{tabular}

${ }^{\mathrm{a}}$ Reproduced from (6) with permission. 
4. Count the cells and mix them to a ratio of splenocyte:Sp2/O-Ag14=3:1. Spin the cells down and remove the supernatant thoroughly.

5. Add $0.5 \mathrm{ml}$ PEG/RPMI solution to the cell pellet slowly (taking about $60 \mathrm{sec}$ ), loosening of cell pellet using the tip of a pipette. Stir the cell clumps gently with a pipette for additional $90 \mathrm{sec}$. The cells should be seen as small aggregates in this step.

6. Add $10 \mathrm{ml}$ of prewarmed $\left(37^{\circ} \mathrm{C}\right)$ RPMI slowly, taking 3-4 min for the first $1 \mathrm{ml}$ drop by drop, and then taking about $6 \mathrm{~min}$ for the remaining $9 \mathrm{ml}$.

7. Incubate the tube at $37^{\circ} \mathrm{C}$ for at least $20 \mathrm{~min}$.

8. Wash the cells twice with prewarmed RPMI.

9. Suspend the cells with HAT-medium to a concentration of $3-5 \times 10^{4} \mathrm{Sp} 2 / \mathrm{O}-$ Ag14 cells $/ \mathrm{ml}$ and plate to $0.2 \mathrm{ml} /$ well of the 96 -well plates.

10. Feed the cells with HAT-medium by changing two-thirds of the volume of the wells on the days 3,7 , and 12 .

11. The hybridoma colonies should be seen by microscope on days 3-7 and some fast-growing colonies should be recognizable by eye from day 7 . Generally, if the immunization and cell fusion step was successful, more than $70 \%$ of the wells contain hybridoma colonies. When the sizes of the colonies becomes one-tenth to one-fifth of the 96-well bottom area, the first screening of positive clones should be taken by ELISA (see Section 3.3).

12. The hybridoma cells in the ELISA-positive wells are recovered and cloned by a limiting dilution method as follows. Cells are counted, diluted with HATmedium, and plated into 96-well plates so that one well contains three or ten cells; the left-half of the plate contains three cells/well and the right-half of the plate contains ten cells/well.

13. The hybridoma colonies will be discernible after 7-10 days. Then the ELISA test should be performed again and the ELISA-positive wells containing single colonies are selected.

14. The cells from the selected wells are expanded in a 24-well plate and adapted to HT-medium for at least 1 week.

15. The cells are further adapted to the hybridoma medium for 1 week. If necessary, the cells are further adapted to a serum-free hybridoma medium.

16. The hybridomas are now ready for collecting the mAbs. The aliquots of the cells are resuspended in freezing buffer and stored at $-135^{\circ} \mathrm{C}$ or in liquid nitrogen.

\subsection{Screening of Anti-SARS-CoV-Producing Hybridomas by ELISA}

The first screening is conducted by ELISA using SARS-CoV-infected Vero E6 cell lysate as the antigen. In this first screening, the uninfected Vero E6 cell lysate is used as the antigen for a negative control. In the case of the assay for the test bleed of immunized mice, the serial dilution of the sera with PBS-Tween (start from 1/20 dilution) is used in place of hybridoma culture supernatants.

1. The Vero cell lysate is prepared as follows. After the inactivation of virus by UV-irradiation, the cell lysate is prepared in NP-40lysis buffer followed by 
centrifugation at $15,000 \times g$ for $20 \mathrm{~min}$ to remove cell debris (see Note 2). The supernatant is used as SARS-CoV-infected Vero cell lysate and the aliquots are stored at $-20^{\circ} \mathrm{C}$. The uninfected Vero cells are treated in exactly the same way and used as the uninfected Vero cell lysate for the negative control plate.

2. The SARS-CoV-infected Vero cell lysate is diluted 100-fold using ELISA-coating buffer and the 96-well ELISA plates are antigen-coated by this solution as $0.1 \mathrm{ml} /$ well at $4{ }^{\circ} \mathrm{C}$ overnight.

3. The ELISA plates are washed with PBS-Tween twice and blocked with blocking solution (1\% OVA in PBS-Tween) at room temperature for $1 \mathrm{~h}$. Plates are washed once with PBS-Tween and $0.05 \mathrm{ml}$ of PBS-Tween is added to each well.

4. The $0.05 \mathrm{ml}$ of culture supernatants from HAT-selected hybridomas are transferred to each well and incubated at room temperature for $1 \mathrm{~h}$ (see Note 3 ).

5. After washing three times with PBS-Tween, $0.1 \mathrm{ml} /$ well of the second antibody (alkaline phosphatase-conjugated anti-mouse IgG, diluted to 1/1000-1/5000 with PBS-Tween) is added and left at room temperature for $1 \mathrm{~h}$.

6. After washing four times with PBS-Tween, $0.1 \mathrm{ml} /$ well of the substrate solution (PNPP) is added. The color development (bright yellow) is stopped by adding $0.05 \mathrm{ml}$ of $0.1 \mathrm{M}$ EDTA and quantified by $\mathrm{OD}_{405}$.

\subsection{Purification of Anti-SARS-CoV Monoclonal Antibody}

1. Hybridomas are grown in about 2 liters of serum-free hybridoma medium to the late-log phase/early stationary phase.

2. The culture supernatants are harvested by centrifugation at $1700 \times g$ for $20 \mathrm{~min}$, and $1 / 100$ volume of $1 \mathrm{M}$ Tris- $\mathrm{HCl}\left(\mathrm{pH} \mathrm{7.4)}\right.$ and $1 / 500$ volume of $10 \% \mathrm{NaN}_{3}$ are added.

The following steps are carried out at $4^{\circ} \mathrm{C}$ (in a cold room) or on ice.

3. The Protein G-sepharose 6B column ( $2-5 \mathrm{ml}$ bed volume) is preequilibrated with PBS and the supernatant is loaded at a flow rate of about 1 drop $/ 5 \mathrm{sec}$. This step takes 2-3 days.

4. The column is washed with PBS and the bound antibody is eluted with glycine/ $\mathrm{HCl}$ solution. In this step, 1-ml fractions are collected into an Eppendorf tube that contains $0.1 \mathrm{ml}$ of $1 \mathrm{M}$ Tris- $\mathrm{HCl}(\mathrm{pH} 8.0)$.

5. After measuring the $\mathrm{OD}_{280}$ of the fractions, the protein-containing fractions are pooled. An equal volume of saturated $\left(\mathrm{NH}_{4}\right)_{2} \mathrm{SO}_{4}$ is gradually added to the pooled fraction. The solution is kept on ice overnight.

6. Precipitated proteins are collected by centrifugation at $2300 \times g$ for $30 \mathrm{~min}$ and the pellet is dissolved with a small volume (1-2 ml) of PBS, dialyzed against PBS (three changes of $500 \mathrm{ml}$, more than $3 \mathrm{~h}$ each),

7. The dialyzed sample is centrifuged at $15,000 \times g$ for $20 \mathrm{~min}$, aliquoted, and stored at $-20^{\circ} \mathrm{C}$.

This procedure generally gives $2-10 \mathrm{mg}$ of purified $\mathrm{mAb}$ from a 2-liter culture of hybridomas. 


\subsection{Biotinylation of Monoclonal Antibodies}

1. The protein concentration of the purified antibody is determined by $\mathrm{OD}_{280}$ using a molecular extinction coefficient equal to 1.4 (for immunoglobulins).

2. The protein concentration is adjusted to $2 \mathrm{mg} / \mathrm{ml}$ with $\mathrm{PBS}$, and $1 \mathrm{ml}$ is dialyzed against $50 \mathrm{mM}$ sodium bicarbonate buffer $(\mathrm{pH} 8.5)$ at $4^{\circ} \mathrm{C}$.

3. Dissolve $1 \mathrm{mg}$ of sulfo-NHS-LC-biotin in $1 \mathrm{ml}$ of distilled water, and quickly add $74 \mu \mathrm{l}$ of this solution to the antibody solution. Mix well and stand in ice for $2 \mathrm{~h}$.

4. Dialyze the solution against PBS at $4{ }^{\circ} \mathrm{C}$ overnight with three changes of $500 \mathrm{ml}$ PBS dialysis solution, each for more than $3 \mathrm{~h}$.

5. The sample is transferred to an Eppendorf tube and centrifuged at 15,000 $\times g$, $4^{\circ} \mathrm{C}$ for $20 \mathrm{~min}$.

6. The supernatant is recovered and the protein concentration is determined by $\mathrm{OD}_{280}$ as above. The aliquots are stored at $-20^{\circ}$ to $-80^{\circ} \mathrm{C}$. Avoid repeated freeze-thawing. The working solution can be stored at $4^{\circ} \mathrm{C}$ for months to years. Preservatives such as sodium azide can be added to $0.05 \%$ if necessary.

\subsection{Immunofluorescence Assay}

1. Virus-infected cells such as Vero E6 cells are cultivated on Lab-Tek 8-well glass chamber slides.

2. The cells are washed with PBS twice and fixed with $4 \%$ paraformaldehyde for $10 \mathrm{~min}$ at room temperature.

3. The cells are washed three times for 5 min each time with PBS and quenched with $50 \mathrm{mM} \mathrm{NH}_{4} \mathrm{Cl}$ for $10 \mathrm{~min}$ at room temperature.

4. The cells are then permeabilized with PBS/TritonX-100 for $5 \mathrm{~min}$ and washed twice with PBS-Tween.

5. The cells are equilibrated with IFA-staining buffer for $1 \mathrm{~h}$ at room temperature.

6. The biotinylated $\mathrm{mAb}$ is diluted with the IFA-staining buffer and cells are stained with the solution for $1 \mathrm{~h}$ at room temperature (see Note 4 ).

7. The cells are washed three times for 5 min each time with PBS-Tween.

8. The second reagent such as Texas red-streptavidin is diluted with the IFAstaining buffer (see Note 4) and cells are stained with the solution for $1 \mathrm{~h}$ at room temperature.

9. The cells are washed three times for 5 min each time with PBS-Tween. If double staining of DNA-containing structures (nuclei) is desired, DAPI can be added to the second wash.

10. An antifade mounting solution such as Fluoromount $\mathrm{G}$ is gently dropped onto the cells and a cover slip carefully placed over them. The edge of the cover slip is sealed by nail varnish.

11. The slides are left to stand for $1 \mathrm{~h}$ at room temperature or overnight at $4{ }^{\circ} \mathrm{C}$ to support the antifade effect.

12. The slide is ready for confocal microscopy, with the excitation/emission wavelength for Texas red $(596 \mathrm{~nm} / 615 \mathrm{~nm})$ and DAPI $(358 \mathrm{~nm} / 461 \mathrm{~nm})$. 

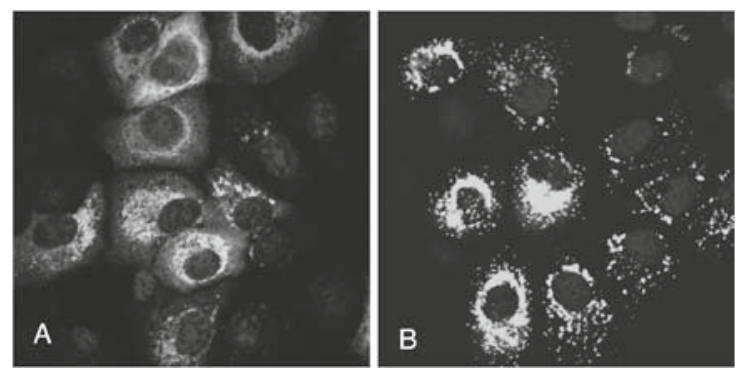

Fig. 1. Fluorescent immunostaining of SARS-CoV-infected Vero E6 cells with monoclonal antibodies (mAb). SARS-CoV-infected Vero E6 cells are paraformaldehydefixed, permeabilized with Trion X-100/PBS-Tween, and incubated with biotinylated mAbs. TexasRed-streptavidine is used for the detecting reagent and the nuclei are stained with DAPI: (A) Anti-S mAb, SKOT-3. (B) Anti-N mAb, SKOT-8.

Figure 1 shows an example of confocal microscopic observation of SARSCoV-infected Vero E6 cells stained with anti-S mAb, SKOT-3 (A), and anti-N mAb, SKOT-8 (B). The nuclei are stained with DAPI.

\subsection{Immunoblot with Monoclonal Antibodies}

1. UV-inactivated purified SARS-CoV is electrophoresed and blotted to PVDF membrane by the standard procedure (see Note 5).

2. The blotted PVDF membrane is blocked with Starting Block ${ }^{\mathrm{TM}}$ solution for $1 \mathrm{~h}$ at room temperature.

3. The membrane is reacted with the first mAbs diluted to $1 \mu \mathrm{g} / \mathrm{ml}$ (see Note 4) with $10 \%$ Starting Block ${ }^{\mathrm{TM}} / \mathrm{PBS}-$ Tween for $1 \mathrm{~h}$ at room temperature. This incubation is done by placing the PVDF membrane in the hybridization bag with $5 \mathrm{ml}$ of antibody solution.

4. The membrane is washed with excess volume (about 20-30 ml) of PBS-Tween three times for 5 min each time in an appropriate container.

5. The membrane is reacted with peroxidase-conjugated $\mathrm{F}\left(\mathrm{ab}^{\prime}\right)_{2}$ fragment anti-mouse IgG diluted to $1: 20,000$ by $10 \%$ Starting Block ${ }^{\mathrm{TM}} / \mathrm{PBS}$-Tween (see Note 4 ). The incubation is done in the hybridization bag for $1 \mathrm{~h}$ at room temperature.

6. The membrane is washed thoroughly with PBS-Tween four times for $5 \mathrm{~min}$ each time.

7. After washing, the membrane is placed on $3 \mathrm{MM}$ filter paper and the liquid is removed but not dried. The membrane is then soaked with West Femto $A: B=$ 1:1 mixture (in case of minigel size, i.e., $7 \times 9 \mathrm{~cm}, 0.8-1.0 \mathrm{ml}$ of $\mathrm{A}: \mathrm{B}$ mixture is required). The membrane should be completely soaked with excess volume of A:B mixture.

8. The membrane is picked up by a flat-tip forceps and placed in between two transparent polyester sheets (see Note 6). 


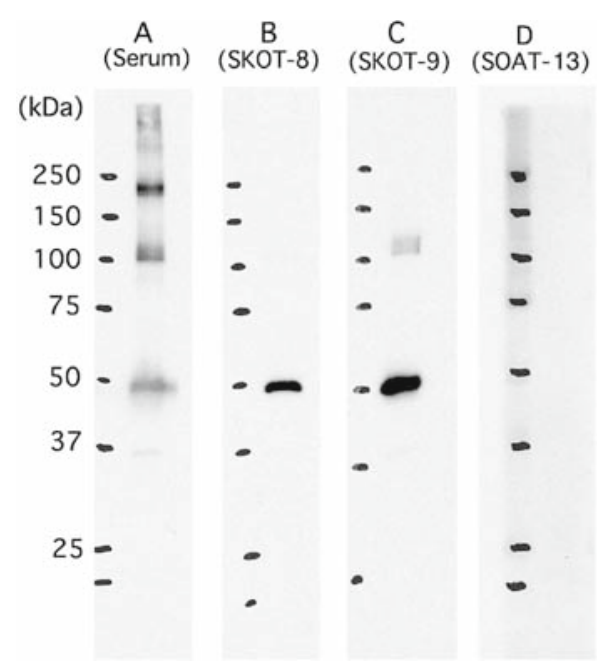

Fig. 2. Immunoblot of SARS-CoV proteins with monoclonal antibodies. Purified SARS-CoV proteins ( $0.5 \mu \mathrm{g} / \mathrm{lane}$ ) are electrophoresed with SDS-PAGE (under reducing conditions), blotted to PVDF membrane, and detected by incubation with mAbs against SARS-CoV proteins. The detection is done with peroxidase-labeled-F $\left(\mathrm{ab}^{\prime}\right)_{2}$ anti-mouse IgG followed by chemiluminescent reaction: (A) Mouse serum from SARS-CoV immunized mouse. (B) Anti-N mAb, SKOT-8. (C) Anti-N mAb, SKOT-9. (D) Anti-S mAb, SOAT13. The positions of molecular weight markers are shown on the left. (Reproduced from (6) with permission.)

9. The membrane/transparent sheet sandwich is placed in an X-ray film cassette with film and exposed for an appropriate time to obtain the best signals.

An example of the result is shown in Fig. 2, in which the purified SARS-CoV proteins $(0.5 \mu \mathrm{g} / \mathrm{lane})$ are electrophoresed with SDS-PAGE, blotted to PVDF membrane, and detected by anti-S and anti-N mAbs.

\subsection{Antigen-Capture Sandwich ELISA}

For the diagnosis of SARS-CoV infection, serological tests such as immunofluorescence assay (IFA, described above) and antigen-capture ELISA assay are two good options for detecting virus in, e.g., respiratory swabs or in virus-infected cells. By utilizing established mAbs against SARS-CoV, it is possible to construct a highly sensitive antigen-capture sandwich ELISA test system for detection of SARS-CoV. The sandwich ELISA consists of two mAbs, an antigen-capturing antibody and a detecting antibody, which recognize different epitopes of the target antigen. The antigen-capturing antibody is immobilized 


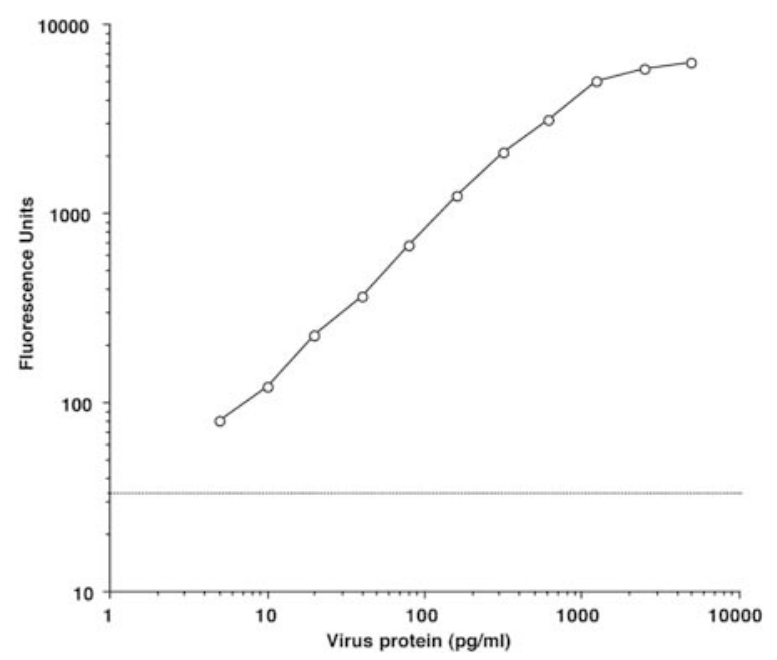

Fig. 3. Antigen-capture sandwich ELISA of SARS-CoV. Anti-N mAb, SKOT-8, is immobilized on the surface of a 96-well plate. Serially titrated purified SARS-CoV fractions are reacted for $1 \mathrm{~h}$ at room temperature and the bound virus proteins are detected by biotinylated SKOT-9 (anti-N) antibody followed by $\beta$-D-galactosidaselabeled streptavidin. They are then quantified by a chemiluminescent reaction using 4-methyl-umbelliferyl- $\beta$-D-galactoside as a substrate: (abscissa) concentration of purified SARS-CoV proteins; (ordinate) fluorescent unit. (Reproduced from (6) with permission.)

on the ELISA plate and captures the viral antigens in the test sample. The detecting antibody is normally labeled with a signal-producing enzyme such as a peroxidase or a phosphatase. The following method is the basic procedure for constructing a sandwich ELISA (see Note 7).

1. Purified $\mathrm{mAb}$ for the antigen-capture is immobilized on an Immulon-2 microplate by incubating $4 \mu \mathrm{g} / \mathrm{ml}$ antibody in the ELISA-coating buffer at $4{ }^{\circ} \mathrm{C}$ overnight.

2. The microplate is blocked with $1 \%$ OVA for $1 \mathrm{~h}$ at room temperature or overnight at $4{ }^{\circ} \mathrm{C}$.

3. The plate is washed three times with PBS-Tween.

4. The UV-inactivated purified SARS-CoV samples (see Note 1), which are serially diluted with $1 \%$ OVA/PBS-Tween, are added to the wells and incubated for $1 \mathrm{~h}$ at room temperature.

5. After washing three times with PBS-Tween, wells are reacted with biotinylated detecting (second) $\mathrm{mAb}(0.1 \mu \mathrm{g} / \mathrm{ml})$ for $1 \mathrm{~h}$ at room temperature.

6. After washing three times with PBS-Tween, wells are reacted with $\beta$-Dgalactosidase-labeled streptavidine for $1 \mathrm{~h}$ at room temperature. 
7. After washing four times with PBS-Tween, fluorescent substrate 4-methylumbelliferyl- $\beta$-D-galactoside is added and incubated for $2 \mathrm{~h}$ at $37^{\circ} \mathrm{C}$.

8. The reaction is stopped by adding one-half volume of $0.1 \mathrm{M}$ glycine- $\mathrm{NaOH}$ (pH 10.2).

9. The fluorescence of the reaction product, 4-methyl-umbelliferone (4-MU), is measured using FluoroScan II (Flow Laboratories Inc., Inglewood, CA) at excitation and emission wavelengths of 355 and $460 \mathrm{~nm}$, respectively.

Figure 3 shows an example of an antigen-capture ELISA system for SARS$\mathrm{CoV}$, in which two anti-N mAbs, SKOT-8 (coating mAb) and biotinylated SKOT-9 (detecting mAb) are used. This sandwich ELISA detects SARS-CoV protein at a concentration as low as $40 \mathrm{pg} / \mathrm{ml}(\mathbf{6})$.

\section{Notes}

1. For further understanding and detailed explanations of the hybridoma methodology, good textbooks are available $(\mathbf{1 0 , 1 1 )}$.

2. The validation for the complete inactivation of the virus is crucial. For a detailed account see Chapter 11 in this volume.

3. In this step the culture supernatants are diluted to one-half in order to reduce the background of the ELISA. If the background is still high, dilution of the culture supernatants can be one-fifth to one-tenth or more with PBS-Tween.

4. The titration of the mAbs and the second reagent is very important for obtaining the best results. It often varies from $1 / 100$ to $1 / 100,000$, and it should be determined for each mAb.

5. The SDS-polyacrylamide gel electrophoresis (PAGE) is carried out by the method of Laemmli (12). The detailed conditions, such as the concentration of the gel or reducing/nonreducing and so on, should be changed case by case. Generally, loading $0.5-10 \mu \mathrm{g} / \mathrm{lane}$ of purified virus fraction would be enough for the detection of the viral antigen by the chemiluminescence method.

6. We conveniently utilize transparent sheets such as those used for an overhead projector (OHP-sheet).

7. In order to obtain good sensitivity and specificity of the test system, the optimization of the combination of two antibodies, i.e., coating mAb and detecting $\mathrm{mAb}$, is required. This can be done by the ELISA with a matrix of candidate coating-mAbs and detecting-mAbs (6).

\section{Acknowledgments}

The author would like to thank Drs. Fumihiro Taguchi and Shigeru Morikawa for their advice and discussion, Dr. Koji Ishii for providing recombinant SARSCoV proteins, and Ms. Sayuri Yamaguchi for her technical assistance. This work was supported by grant from the Ministry of Public Health and Labor of Japan. 


\section{References}

1. Drosten, C., Gunther, S., Preiser, W., van der Werf, S., Brodt, H. R., Becker, S., Rabenau, H., Panning, M., Kolesnikova, L., Fouchier, R. A., et al. (2003) Identification of a novel coronavirus in patients with severe acute respiratory syndrome. N. Engl. J. Med. 348, 1967-1976.

2. Ksiazek, T. G., Erdman, D., Goldsmith, C. S., Zaki, S. R., Peret, T., Emery, S., Tong, S., Urbani, C., Comer, J. A., Lim, W., et al. (2003) A novel coronavirus associated with severe acute respiratory syndrome. N. Engl. J. Med. 348, 19531966.

3. Peiris, J. S., Chu, C. M., Cheng, V. C., Chan, K. S., Hung, I. F., Poon, L. L., Law, K. I., Tang, B. S., Hon, T. Y., Chan, C. S., et al. (2003) Clinical progression and viral load in a community outbreak of coronavirus-associated SARS pneumonia: a prospective study. Lancet 361, 1767-1772.

4. Chan, P. K., To, W .K., Ng, K. C., Lam, R. K., Ng, T. K., Chan, R. C., Wu, A., Yu, W. C., Lee, N., Hui, D. S., et al. (2004) Laboratory diagnosis of SARS. Emerg. Infect. Dis. 10, 825-831.

5. Wang, W. K., Chen, S. Y., Liu, I. J., Chen, Y. C., Chen, H. L., Yang, C. F., Chen, P. J., Yeh, S. H., Kao, C. L., Huang, L. M., et al. (2004) Detection of SARS-associated coronavirus in throat wash and saliva in early diagnosis. Emerg. Infect. Di.s 10, 1213-1219.

6. Ohnishi, K., Sakaguchi, M., Kaji, T., Akagawa, K., Taniyama, T., Kasai, M., Tsunetsugu-Yokota, Y., Oshima, M., Yamamoto, K., Takasuka, N., et al. (2005) Immunological detection of severe acute respiratory syndrome coronavirus by monoclonal antibodies. Jpn. J. Infect. Dis. 58, 88-94.

7. Che, X. Y., Qiu, L. W., Pan, Y. X., Wen, K., Hao, W., Zhang, L. Y., Wang, Y. D., Liao, Z. Y., Hua, X., Cheng, V. C., et al. (2004) Sensitive and specific monoclonal antibody-based capture enzyme immunoassay for detection of nucleocapsid antigen in sera from patients with severe acute respiratory syndrome. $J$. Clin. Microbiol. 42, 2629-2635.

8. Tsunetsugu-Yokota, Y., Ato, M., Takahashi, Y., Hashimoto, S.-I., Kaji, T., Kuraoka, M., Yamamoto, K.-I., Mitsuki, Y.-Y., Yamamoto, T., Ohshima, M., et al. (2007) Formalin-treated UV-inactivated SARS coronavirus vaccine retains its immunogenicity and promotes Th2-type immune responses. Jpn. J. Infect. Dis. In press.

9. Kozbor, D., and Roder, J. C. (1984) In vitro stimulated lymphocytes as a source of human hybridomas. Eur. J. Immunol. 14, 23-27.

10. Harlow, E., and Lane, D. (1998) Using Antibodies: A Laboratory Manual. Cold Spring Harbor Laboratory, New York.

11. Shepherd, P., and Dean, C. (2000) Monoclonal Antibodies: A Practical Approach: Oxford University Press, New York.

12. Laemmli, U. K. (1970) Cleavage of structural proteins during the assembly of the head of bacteriophage T4. Nature 227, 680-685. 